\title{
The Current Process for the Recycling of Spent Lithium Ion Batteries
}

\author{
Li-Feng Zhou ${ }^{1}$, Dongrun Yang ${ }^{2}$, Tao Du ${ }^{1 *}, \mathrm{He}_{\mathrm{Gong}}{ }^{1}$ and Wen-Bin Luo ${ }^{1,2 *}$ \\ ${ }^{1}$ Section of Environmental Protection (SEP) Key Laboratory of Eco-Industry, School of Metallurgy, Northeastern University, \\ Shenyang, China, ${ }^{2}$ School of Metallurgy, Institute for Energy Electrochemistry and Urban Mines Metallurgy, Northeastern \\ University, Shenyang, China
}

With the development of electric vehicles involving lithium ion batteries as energy storage devices, the demand for lithium ion batteries in the whole industry is increasing, which is bound to lead to a large number of lithium ion batteries in the problem of waste, recycling and reuse. If not handled properly, it will certainly have a negative impact on the environment and resources. Current commercial lithium ion batteries mainly contain transition metal oxides or phosphates, aluminum, copper, graphite, organic electrolytes containing harmful lithium salts, and other chemicals. Therefore, the recycling and reuse of spent lithium ion batteries has been paid more and more attention by many researchers. However, due to the high energy density, high safety and low price of lithium ion batteries have great differences and diversity, the recycling of waste lithium ion batteries has great difficulties. This paper reviews the latest development of the recovery technology of waste lithium ion batteries, including the development of recovery process and products. In addition, the challenges and future economic and application prospects are described.

\footnotetext{
Keywords: spent lithium ion batteries, cathode materials, pyrometallurgical process, hydrometallurgical process, direct physical recycling process
}

\section{INTRODUCTION}

dut@smm.neu.edu.cn Wen-Bin Luo

luowenbin@smm.neu.edu.cn

Specialty section

This article was submitted to Green and Sustainable Chemistry,

a section of the journal

Frontiers in Chemistry

Received: 30 June 2020 Accepted: 07 October 2020 Published: 03 December 2020

Citation:

Zhou L-F, Yang D, Du T, Gong $H$ and Luo W-B (2020) The Current Process for the Recycling of Spent Lithium Ion

Batteries. Front. Chem. 8:578044.

doi: 10.3389/fchem.2020.578044
In the early 1990s, Moli and Sony used carbon materials with graphite structure to replace metal lithium anodes, and lithium and transition metal composite oxide such as $\mathrm{LiCoO}_{2}$ served as the cathodes, leading to the commercialization of LIBs (Arora et al., 1998; Song et al., 1999; Lee and Lee, 2000; Pattipati et al., 2014). With the popularity of portable electronic devices such as mobile phones and tablet computers in recent years, LIBs have gradually been recognized. What really shakes the lithium resource reserve to promote the development of LIBs is the development of EVs. In the past few years, with the development of energy storage industry, LIBs with higher energy density and higher power output have been widely used in EVs. In particular, attention should be paid to the battery development of BYD and Tesla. At the same time, with the policy orientation and the convenience and benefits brought by EVs, the global EV market is developing rapidly. Figures $\mathbf{1 A , B}$ show the development of EVs worldwide, with particular attention to the development of EVs in China and the United States. It can be seen that since 2015, the global stock and registration of EVs have grown rapidly, and China and the United States have shown an amazing growth trend. In 2019 , China's EV stock reached 3,810,000, nearly half of the global total and 2.6 times that of the US, and the number of China's EV registrations was 1,204,000, more than half of the global total and almost 4 times that of the US. BYD and Tesla are the two most prominent EV companies, with more 

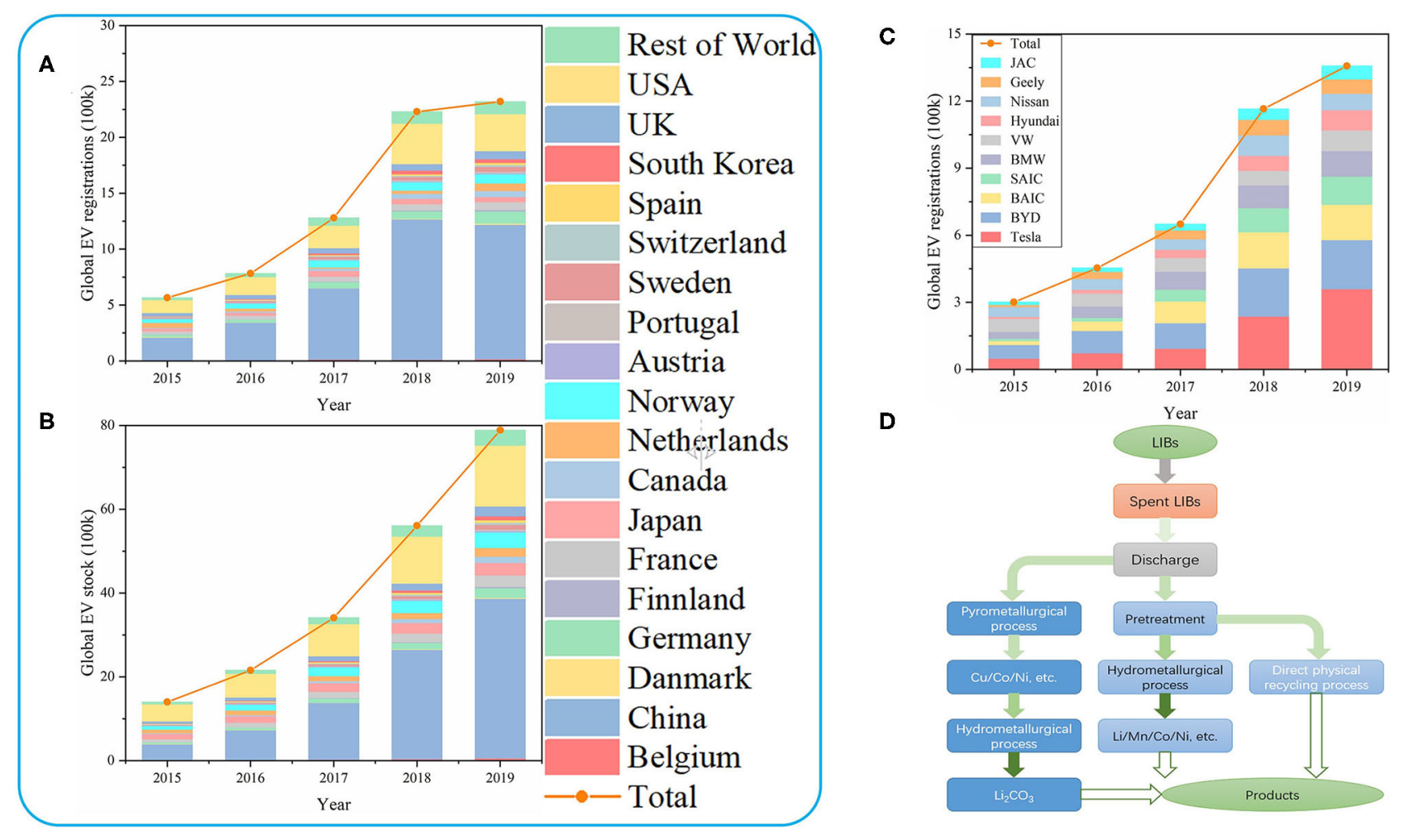

FIGURE 1 | (A) The global registration of EVs. (B) The global stock of EVs. (C) The global company registration of EVs. (D) Recovery methods for spent LIBs.

than $40 \%$ of the world's $1,357,000$ registrations in $2019^{1}$ (Figure 1C). They are represented by $\mathrm{LiFePO}_{4}$ and $\mathrm{LiNi}_{1-x-y} \mathrm{Co}_{x} \mathrm{Mn}_{y} \mathrm{O}_{2}$ (NCM) (Zhu, 2014). Considering the blowout development of EVs, the disposal of the huge amount of spent lithium-ion batteries (LIBs) brought about by the exhaustion of the life cycle of LIBs will soon become a huge problem that plagues society. Therefore, we should be alert to the upcoming troubles and actively develop the technology and technical level related to the disposal of spent LIBs (Villen-Guzman et al., 2019).

Due to the short history of LIBs, a systematic recycling system has not yet been formed. Generally, a LIB includes a cathode, an anode, a separator, electrolyte, and a case with a sealing function. There are many types of commercial LIBs, mainly including lithium oxides and phosphides, such as $\mathrm{LiCoO}_{2}, \mathrm{LiMn}_{2} \mathrm{O}_{4}$, $\mathrm{LiFePO}_{4}, \mathrm{NCM}$, etc. Since 2012, due to the development of EV markets, $\mathrm{LiFePO}_{4}$ and $\mathrm{LiNi}_{0.33} \mathrm{Co}_{0.33} \mathrm{Mn}_{0.33} \mathrm{O}_{2}$ have occupied more than half of the cathode material market. The electrolyte in the LIBs also contains harmful substances, such as organic solvents and fluorine-containing lithium salts, which may cause great harm to the environment. Therefore, if spent LIBs directly puts in the environment, it will cause an irreversible environmental disaster. In addition, the high-priced metals contained in LIBs, such as $\mathrm{Li}, \mathrm{Co}, \mathrm{Ni}, \mathrm{Cu}, \mathrm{Al}$, etc., also have good resource value. In the spent electrode materials, the average

${ }^{1}$ https://www.zsw-bw.de/en/media-center/data-service.html\#c8750 content of $\mathrm{Li}$ is about $5 \mathrm{wt} \%$, which is much higher than the content in natural ores and has recycling value. Besides, environmental and economic issues are also prerequisites for LIBs recycling. Many organic electrolytes and heavy metal ions have been released into groundwater by battery abandonment and leakage and have proved to be harmful to human health and the ecological environment. In addition, Choubey et al. (2016) reported the economic value of lithium-ion battery recycling, which can generate an economic benefit of $\$ 22,000$ per ton by calculating the value of lithium and cobalt.

In view of the above reasons, the recycling of spent LIBs has a considerable prospect and is environmentally friendly, so it is imperative to establish a reasonable recycling system and develop related recycling technologies. This article will summarize hydrometallurgical process, pyrometallurgical process and direct physical recycling process (Figure 1D) and summarize the strengths and weaknesses of them (Table 1).

\section{THE METHODS OF RECOVERING LITHIUM ION BATTERIES}

Recycling for LIBs usually involves both physical and chemical processes (Harper et al., 2019). Due to the complex assembly process of LIBs and the wide variety of electrodes, it brings great danger for the recovery of battery. The explosion, combustion and poisonous gas brought on the recovery 
TABLE 1 | Comparisons of advantages and disadvantages and challenges for different methods.

\begin{tabular}{|c|c|c|c|}
\hline Process & Advantages & Disadvantages & Challenge \\
\hline $\begin{array}{l}\text { Hydrometallurgical } \\
\text { process }\end{array}$ & $\begin{array}{l}\text { High recovery } \\
\text { rate } \\
\text { High purity } \\
\text { product } \\
\text { Low energy } \\
\text { consumption } \\
\text { Less waste gas } \\
\text { High Selectivity }\end{array}$ & $\begin{array}{l}\text { More wastewater } \\
\text { Long process }\end{array}$ & $\begin{array}{l}\text { Wastewater } \\
\text { treatment } \\
\text { Optimize } \\
\text { the process }\end{array}$ \\
\hline $\begin{array}{l}\text { Pyrometallurgical } \\
\text { process }\end{array}$ & $\begin{array}{l}\text { Simple operation } \\
\text { and short flow } \\
\text { No requirement } \\
\text { for categories } \\
\text { and the size of } \\
\text { inputs } \\
\text { High efficiency }\end{array}$ & $\begin{array}{l}\text { Li and Mn are not } \\
\text { recovered } \\
\text { High energy } \\
\text { consumption } \\
\text { Low recovery } \\
\text { efficiency } \\
\text { More waste gas } \\
\text { and the cost of } \\
\text { waste } \\
\text { gas treatment }\end{array}$ & $\begin{array}{l}\text { Reduce energy } \\
\text { consumption and } \\
\text { pollution emissions } \\
\text { Reduce } \\
\text { environmental } \\
\text { hazards } \\
\text { Combine } \\
\text { hydrometallurgy well }\end{array}$ \\
\hline $\begin{array}{l}\text { Direct physical } \\
\text { recycling } \\
\text { process }\end{array}$ & $\begin{array}{l}\text { Short recovery } \\
\text { route } \\
\text { Low energy } \\
\text { consumption } \\
\text { Environmental } \\
\text { friendly } \\
\text { High } \\
\text { recovery rate }\end{array}$ & $\begin{array}{l}\text { High operational } \\
\text { and equipment } \\
\text { requirements } \\
\text { Incomplete recovery }\end{array}$ & $\begin{array}{l}\text { Reduce recovery } \\
\text { costs } \\
\text { Lower the } \\
\text { requirements for } \\
\text { categories } \\
\text { Further optimize } \\
\text { product performance }\end{array}$ \\
\hline
\end{tabular}

process are easy to cause casualties. To reduce this risk, spent LIBs usually need to be discharged before recycled. Physical processes usually include pretreatment and direct recovery of electrode materials. These processes usually include disassembly, crushing, screening, magnetic separation, washing, heating treatment, etc. Chemical processes can be divided into pyrometallurgical and hydrometallurgical processes, which usually involve leaching, separation, extraction and chemical/electrochemical precipitation.

\section{Hydrometallurgical Process}

At present, hydrometallurgy is typically used to recover LIBs after pretreatment. According to the physical properties of the materials in the spent LIBs, including morphology, density, and magnetism, etc. The treated battery cases, electrodes and membranes containing electrolytes will be treated separately to improve the safety and recovery rate of hydrometallurgical processes and reduce energy consumption during the use of hydrometallurgical or pyrometallurgical recovery electrode materials. Hydrometallurgy usually involves leaching and reduction. It is usually divided into acid leaching and biological leaching according to the leaching method.

For the acid leaching process, Zhang et al. (1998) reported a recovery rate of over $99 \%$ for Co and $\mathrm{Li}$, and Nan et al. (2005) reported a recovery rate of over $98 \%$ for $\mathrm{Cu}$. The recovery rate of hydrometallurgy is far from that of pyrometallurgy. In the acid leaching of electrode materials, inorganic acids are mostly used, usually including hydrochloric acid ( $\mathrm{HCl}$ ) (Li et al., 2009; Guo et al., 2016; Barik et al., 2017), sulfuric acid $\left(\mathrm{H}_{2} \mathrm{SO}_{4}\right)$ (Dun-Fang et al., 2009; Meshram et al., 2015, 2016), nitric acid $\left(\mathrm{HNO}_{3}\right)(\mathrm{Li}$ et al., 2011; Mossini et al., 2015), and phosphoric acid $\left(\mathrm{H}_{3} \mathrm{PO}_{4}\right)$ (Pinna et al., 2016; Chen et al., 2017), while the organic acids studied include citric acid (Li et al., 2010; Gao et al., 2019; Yu et al., 2019), oxalic acid (Zeng et al., 2015), and tartaric acid (Chen et al., 2019).

Lee and Rhee (2003) used $\mathrm{HCl}$ to recycle $\mathrm{LiCoO}_{2}$ and revealed the principle of acid leaching:

$$
2 \mathrm{LiCoO}_{2}+8 \mathrm{HCl} \rightarrow 2 \mathrm{CoCl}_{2}+\mathrm{Cl}_{2}+2 \mathrm{LiCl}+4 \mathrm{H}_{2} \mathrm{O}
$$

In the process of $\mathrm{HCl}$ leaching (Figure 2A), the solution has a strong ability to leach Co from spent LIBs and reduce $\mathrm{Co}^{3+}$ to $\mathrm{Co}^{2+}$. But the $\mathrm{Cl}_{2}$ produced during leaching is a difficult problem to solve because of its toxicity and corrosiveness. For NCM electrode materials, $\mathrm{HCl}$ solution with strong acidity should not be used in order to slow the dissolution of Mn. Therefore, Castillo et al. (2002) reported the acid hydrolysis process of cathode materials with nitric acid, and achieved the recovery of $100 \% \mathrm{Li}$ and $95 \% \mathrm{Mn}$. In practical application, one of the best ways to solve the problem is to use $\mathrm{H}_{2} \mathrm{SO}_{4}$ hydrolysis and use hydrogen peroxide $\left(\mathrm{H}_{2} \mathrm{O}_{2}\right)$ to reduce the $\mathrm{Co}^{3+}$ to $\mathrm{Co}^{2+}$. The reaction equation is as follows:

$$
\begin{aligned}
2 \mathrm{LiCoO}_{2} & +3 \mathrm{H}_{2} \mathrm{SO}_{4}+\mathrm{H}_{2} \mathrm{O}_{2} \rightarrow 2 \mathrm{CoSO}_{4}+\mathrm{O}_{2}+\mathrm{Li}_{2} \mathrm{SO}_{4} \\
& +4 \mathrm{H}_{2} \mathrm{O}
\end{aligned}
$$

For inorganic acids, temperature, $\mathrm{pH}$ value, reaction time, additives and so on have a significant impact on the leaching performance. Li et al. (2009) reported that under the condition of $80^{\circ} \mathrm{C}, 4 \mathrm{M} \mathrm{HCl}$ solution was leached for $2 \mathrm{~h}, 99 \% \mathrm{Co}$ and 97\% $\mathrm{Li}$ were dissolved. Jha et al. (2013) reported that $\mathrm{LiCoO}_{2}$ was leaching $2 \mathrm{M} \mathrm{H}_{2} \mathrm{SO}_{4}$ and $5 \% \mathrm{H}_{2} \mathrm{O}_{2}(\mathrm{~V} / \mathrm{V})$ for $1 \mathrm{~h}$ at $75^{\circ} \mathrm{C}$, achieving $99.1 \% \mathrm{Li}$ dissolution and $70 \% \mathrm{Co}$ dissolution. Chen et al. (2017) reported the precipitation of $\mathrm{Co}_{3}\left(\mathrm{PO}_{4}\right)_{2}$ were separated from the solution containing lithium ions. And Shih et al. (2019) reported, in the presence of microwaves at $90^{\circ} \mathrm{C}$, Co was completely dissolved and average $90 \%$ of the total metals were leached with $\mathrm{H}_{2} \mathrm{SO}_{4}$. What's more, more than $99.5 \% \mathrm{Mn}$ was recycled from solution. Lee and Rhee (2003) reported that the solubility of $\mathrm{Li}$ and Co was over $95 \%$ at $75^{\circ} \mathrm{C}$ by leaching $1 \mathrm{M}$ $\mathrm{HNO}_{3}$ and $1.7 \% \mathrm{H}_{2} \mathrm{O}_{2}$ (V/V) for $0.5 \mathrm{~h}$ (Pinna et al., 2016). In addition to strong inorganic acids, weak phosphoric acid has also proved to be a good solution for acidolysis. Pinna et al. (2016) reported the leaching performance at a concentration of $0.7 \mathrm{M}$ $\mathrm{H}_{3} \mathrm{PO}_{4}$ and $4 \%$ hydrogen peroxide $(\mathrm{V} / \mathrm{V})$, achieving a recovery of over $99 \%$ of $\mathrm{Li}$ and $\mathrm{Co}$ at $40^{\circ} \mathrm{C}$ for $1 \mathrm{~h}$. The effect of ultrasonic and microwave on leaching reaction was studied (Shih et al., 2019).

In recent years, some mild organic acids have been widely studied. During oxalic acid leaching, leaching and precipitation usually occur simultaneously, resulting in $\mathrm{CoC}_{2} \mathrm{O}_{4}$ precipitation and the separation directly from the $\mathrm{Li}^{+}$solution without further treatment. In addition, because oxalic acid solutions are reductive, no additional reductants are required. Liang and Qiu (2012) reported a recovery rate of more than $98 \%$ of $\mathrm{Li}^{+}$and $\mathrm{Co}^{2+}$ in $1 \mathrm{M}$ acetic acid for $2 \mathrm{~h}$ at $80^{\circ} \mathrm{C}$. Chen X. et al. (2016) reported the leaching performance using citric acid. The recovery 


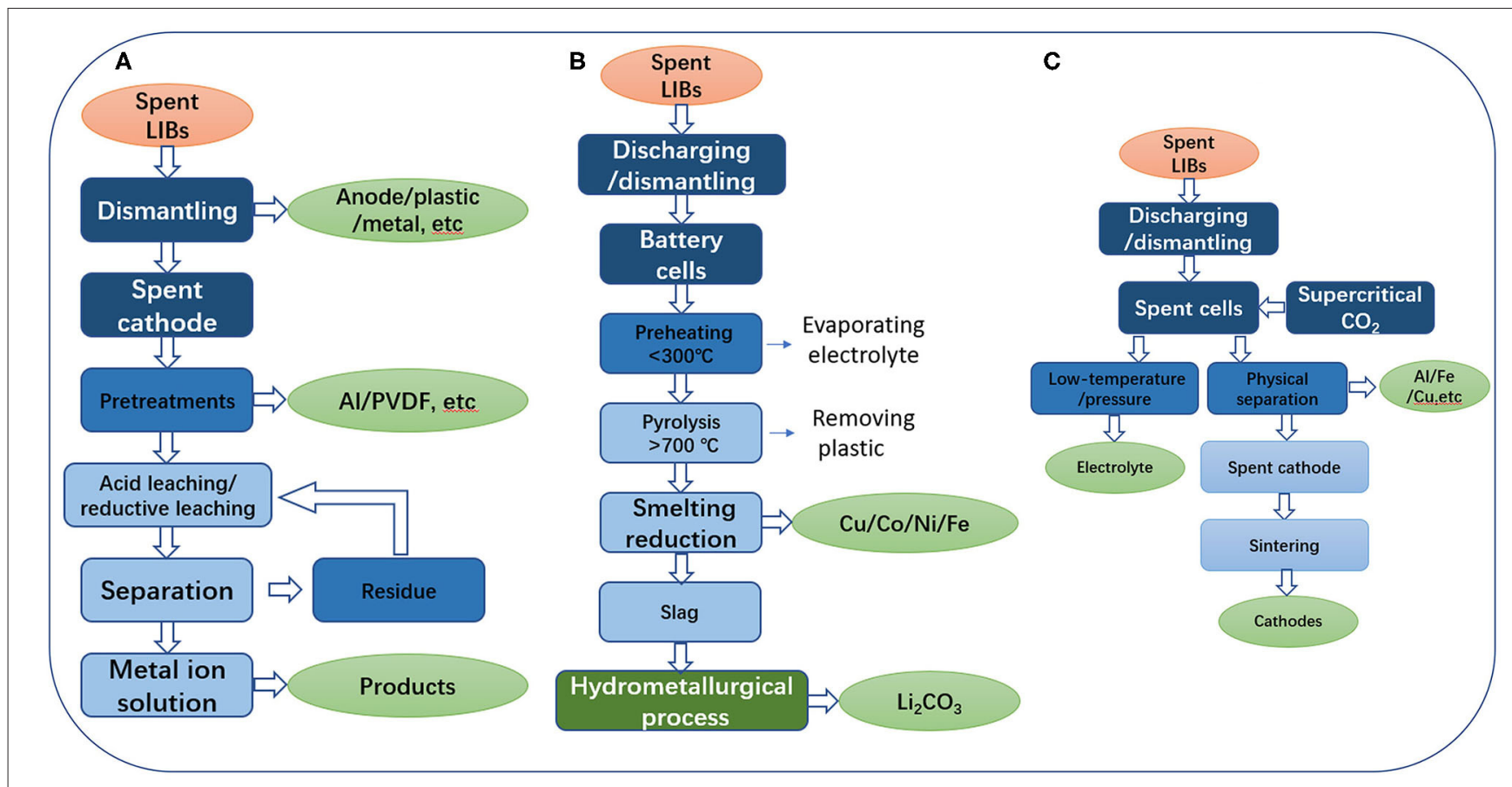

FIGURE 2 | (A) Hydrometallurgical process. (B) Pyrometallurgical process. (C) Direct physical recycling process.

of $99 \% \mathrm{Li}, 93 \% \mathrm{Co}, 91 \% \mathrm{Ni}$ and $94 \% \mathrm{Mn}$ was achieved by leaching the spent electrode material $\mathrm{LiNi}_{1 / 3} \mathrm{Co}_{1 / 3} \mathrm{Mn}_{1 / 3} \mathrm{O}_{2}$ at $80^{\circ} \mathrm{C}$ for $2 \mathrm{~h}$. Chen et al. (2019) showed the recovery performance of $98 \%$ $\mathrm{Co}$ and $97 \% \mathrm{Li}$ and transform spent $\mathrm{LiCoO}_{2}$ to precipitate and Li-enriched solution by tartaric acid.

As a hydrometallurgical process, bioleached metals are extracted by dissolving spent electrode materials with metabolites excreted by microorganisms (bacteria and fungi). Mishra et al. (2008) reported the performance of treating $\mathrm{LiCoO}_{2}$ by chemotrophic and acidophilic bacteria, and Niu et al. (2014) showed the leaching performance of Alicyclobacillus SP for $\mathrm{Li}$ and Co in different concentrations, that decreased, respectively, from 52 to $10 \%$ and from 80 to $37 \%$ with the increase of ore slurry concentration from 1 to $4 \%$. Mohagheghi et al. (2017) reported the performance of Aspergillus Niger. The survival of fungi/bacteria was considered, so the bioleaching was affected by the slurry concentration. Bahaloo-Horeh and Mousavi (2017) reported the similar results of studies related to Aspergillus Niger and reported the effects of electrolytes in the slurry on biology.

\section{Pyrometallurgical Process}

Pyrometallurgy is widely used for the commercial recovery of Co. The commonly used treatment of spent LIBs is similar to the ore smelting (Dunn et al., 2012). Before the smelting process, the modular LIBs are first disassembled into separate cells and then fed into a heating furnace. Batteries are reduced by preheating, pyrolysis and smelting, successively (Schakman et al., 2014; Jing et al., 2018). In the preheating zone, the heating temperature should be lower than $300^{\circ} \mathrm{C}$ to ensure complete evaporation of the electrolyte without explosion. And in the pyrolysis zone, the furnace temperature is controlled above $700^{\circ} \mathrm{C}$. The purpose of this is to remove the plastic from the battery. In the smelting reduction zone, the material is smelted into alloys of $\mathrm{Cu}, \mathrm{Co}, \mathrm{Ni}$, and $\mathrm{Fe}$, along with $\mathrm{Li}, \mathrm{Al}, \mathrm{Si}, \mathrm{Ca}$, and some Fe slag. This method is usually only used to recover $\mathrm{Cu}, \mathrm{Co}, \mathrm{Ni}$, and small amounts of Fe. Since Co plays an irreplaceable role in commercial LIBs, and thermal metallurgy has a high efficiency in recovering Co rather than $\mathrm{Li}$, the economy of this recovery method depends largely on the amount of Co contained in spent LIBs and the fluctuation of market value of cobalt. However, as battery manufacturers consider the value and environmental issues of Co, Co-free electrode materials in LIBs have been continuously developed in recent years, significantly including $\mathrm{LiMn}_{2} \mathrm{O}_{4}$ and $\mathrm{LiFePO}_{4}$, some of which have been commercialized (Etacheri et al., 2011; Huang et al., 2014) ${ }^{2}$. Considering the limitation of lithium resources, this traditional method has no development prospect.

In order to recover $\mathrm{Li}$ from the spent LIBs, the selective pyrolysis method of an arc furnace can be used to convert some electrode materials into Co alloys and Li concentrate. After that, the $\mathrm{Li}$ is extracted by hydrometallurgy, and then it is transshipped and stored through the form of $\mathrm{Li}_{2} \mathrm{CO}_{3}$. And other components can be extracted further. The specific steps are shown in the Figure 2B. This method can be used not only to recycle electrode materials, but also to recycle $\mathrm{Li}$ and $\mathrm{Fe}$, etc. in the electrolyte, which greatly improve the recovery efficiency.

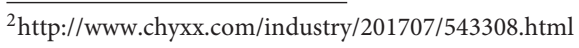


Asadi Dalini et al. (2020) reported the usage scenarios and profit calculation of pyrometallurgy and hydrometallurgy used by different companies. Hydrometallurgy was mainly aimed at the recovery of $\mathrm{Li}_{2} \mathrm{CO}_{3}$ and $\mathrm{Co}_{3} \mathrm{O}_{4}$ and had 10,000-ton processing capacity. Anwani et al. (2020a) reported a laboratory-level life cycle assessment and economic analysis for cobalt oxalate from waste lithium ion batteries through acid leaching and roasting processes. For $3 \mathrm{~g}$ untreated positive electrode materials, the total process consumption of recovering cobalt oxalate was $\$ 0.59$ and $\$ 0.67$ for acid leaching and baking processes, respectively. Recently, Anwani et al. (2020b) reported the cost calculation of waste lithium ion batteries treated by acid leaching once again. According to the type of acid used in the process, the calculation for $10 \mathrm{~g}$ of untreated positive electrode material in $250 \mathrm{~mL}$ acid solution was carried out respectively. The cheapest oxalic acid was $\$ 1.06$ and the most expensive acetic acid was \$2.07.

Considering pyrometallurgy could cause the low recovery efficiency, high energy consumption and the production of toxic gases (dioxins, furans, etc.), the development of high recovery rate, low energy consumption and low environmental hazard recycling process has a good commercial prospect.

\section{Direct Physical Recycling Process}

Direct recovery is a process of recovering useful components from spent LIBs without using chemical methods (Dunn et al., 2012; Yang et al., 2018). Before handling LIBs, they were discharged and disassembled into thousands of cells. Then, the small cells were treated with supercritical $\mathrm{CO}_{2}$, and the electrolytes were extracted and treated in this process. After lowering the temperature and pressure, $\mathrm{CO}_{2}$ can be separated from the electrolyte and the electrolyte can be regenerated. The cells were then disassembled, broken and sorted. Finally, the cathode material was collected and reused (Figure 2C).

Chen J. et al. (2016) reported a technology to directly recycle $\mathrm{LiFePO}_{4}$ from soft-pack batteries. In the case of no recovery of electrolyte, the spent LIBs were disassembled, crushed and cleaned in the sealed box. Due to residual polyvinylidene fluoride (PVDF) binder and material decomposition after thousands of charge and discharge cycles, the energy density of recovered $\mathrm{LiFePO}_{4}$ material is low and its electrochemical performance is poor. After heating treatment at $650^{\circ} \mathrm{C}$, the electrochemical performance was improved, showing almost the same discharge capacity and energy density as the new material. Song et al. (2017) sintered the recovered materials with fresh powder through the physical direct recovery process to regenerate $\mathrm{LiFePO}_{4}$ materials from spent LIBs. The electrochemical performance of the regenerated $\mathrm{LiFePO}_{4}$ battery can meet the basic requirements of reuse. Huang et al. (2018) compared three direct physical recovery processes for graphite anode materials from spent LIBs. The first one was based on graphite heating treatment without recovery of the electrolyte. The second was to extract the electrolyte with subcritical $\mathrm{CO}_{2}$ and then heat it. The third was not only using supercritical $\mathrm{CO}_{2}$ as extraction agent, but also includes electrolyte extraction and heating treatment. Experimental results show that subcritical $\mathrm{CO}_{2}$ extraction electrolyte is the best recovery method. Zhang et al. (2019) reported the liberation efficiency of cathode materials was $98.23 \%$ by direct pyrolysis and physical recovery. Direct physical recovery technology has the advantages of short recovery route, low energy consumption, environmental friendliness and high recovery rate. However, it is not clear whether the recycled material will achieve the long-term properties of the new material.

\section{CONCLUSIONS AND PROSPECTS}

In summary, all of the recycling processes discussed above are designed to recycle resources from spent LIBs. However, due to the different technical difficulties and economic benefits, the development stage of recycling process is not the same. Pyrometallurgy, for example, has been commercialized because of its simplicity and efficiency in recovering Co, the most valuable metal in the spent LIBs. With the development of battery technology, the content of Co in electrode materials is decreasing, while the use of $\mathrm{Ni}$ and manganese is increasing. In addition, the consumption of LIBs has grown rapidly in the past few years due to the rapid expansion of the EV market, and Li reserves have become a top concern. Therefore, the technology of Co recovery should be transferred to the comprehensive utilization of spent Li. In addition, when developing spent leaching recovery process, consideration should be given to appropriate treatment or recovery of certain materials that may pose a risk to the environment, such as electrolytes.

In addition, because the recovery of LIBs is in the initial stage, the current research level and the industrial development level cannot achieve the perfect recovery, namely safety, low cost, low energy consumption and no pollution. So further research and investment is inevitable. In order to better develop recycling technology of LIBs, it is best to do the following aspects: (1) Classify LIBs well according to the type of electrode; (2) Do a good job in battery design to make it meet the conditions of easy regeneration; (3) Cooperation on the recovery of spent LIBs and relevant legislative work around the world.

\section{AUTHOR CONTRIBUTIONS}

L-FZ organized and wrote the manuscript. HG and DY discussed the results. TD and W-BL guided the paper. All authors approved this manuscript.

\section{FUNDING}

This work was supported by the Fundamental Research Funds for the Central Universities (No. N2024001), the Fundamental Research Funds for the Central Universities (Nos. N2025018 and N2025009), the National Natural Science Foundation of China (No. 51904073), and the National Key Research and Development Project (Nos. 2019YFC1905200 and 2017YFB0304001). 


\section{REFERENCES}

Anwani, S., Methekar, R., and Ramadesigan, V. (2020a). Life cycle assessment and economic analysis of acidic leaching and baking routes for the production of cobalt oxalate from spent lithium-ion batteries. J. Mater. Cycles Waste Manag. doi: 10.1007/s10163-020-01095-2. [Epub ahead of print].

Anwani, S., Methekar, R., and Ramadesigan, V. (2020b). Resynthesizing of lithium cobalt oxide from spent lithium-ion batteries using an environmentally benign and economically viable recycling process. Hydrometallurgy 197:105430. doi: 10.1016/j.hydromet.2020.105430

Arora, P., White, R.E., and Doyle, M. (1998). Capacity fade mechanisms and side reactions in lithium-ion batteries. J Electrochem Soc. 145, 3647-3667. doi: $10.1149 / 1.1838857$

Asadi Dalini, E., Karimi, G., Zandevakili, S., and Goodarzi, M. (2020). A review on environmental, economic and hydrometallurgical processes of recycling spent lithium-ion batteries. Miner. Process. Extract. Metallurgy Rev. 197, 1-22. doi: $10.1080 / 08827508.2020 .1781628$

Bahaloo-Horeh, N., and Mousavi, S. M. (2017). Enhanced recovery of valuable metals from spent lithium-ion batteries through optimization of organic acids produced by Aspergillus niger. Waste Manag. 60, 666-679. doi: 10.1016/j.wasman.2016.10.034

Barik, S. P., Prabaharan, G., and Kumar, L. (2017). Leaching and separation of $\mathrm{Co}$ and $\mathrm{Mn}$ from electrode materials of spent lithium-ion batteries using hydrochloric acid: Laboratory and pilot scale study. J. Clean. Prod. 147, 37-43. doi: 10.1016/j.jclepro.2017.01.095

Castillo, S., Ansart, F., Labertyrobert, C., and Portal, J. (2002). Advances in the recovering of spent lithium battery compounds. J. Power Sources 112, 247-254. doi: $10.1016 / \mathrm{S} 0378-7753(02) 00361-0$

Chen, J., Li, Q., Song, J., Song, D., Zhang, L., and Shi, X. (2016). Environmentally friendly recycling and effective repairing of cathode powders from spent LiFePO4 batteries. Green Chem. 18, 2500-2506. doi: 10.1039/C5GC02650D

Chen, X., Fan, B., Xu, L., Zhou, T., and Kong, J. (2016). An atom-economic process for the recovery of high value-added metals from spent lithium-ion batteries. J. Clean. Prod. 112, 3562-3570. doi: 10.1016/j.jclepro.2015.10.132

Chen, X., Kang, D., and Cao, L. (2019). Separation and recovery of valuable metals from spent lithium ion batteries: simultaneous recovery of $\mathrm{Li}$ and $\mathrm{Co}$ in a single step. Sep. Purif. Tech. 210, 690-697. doi: 10.1016/j.seppur.2018.08.072

Chen, X., Ma, H., Luo, C., and Zhou, T. (2017). Recovery of valuable metals from waste cathode materials of spent lithium-ion batteries using mild phosphoric acid. J. Hazard. Mater. 326, 77-86. doi: 10.1016/j.jhazmat.2016.12.021

Choubey, P. K., Kim, M. S., Srivastava, R. R., Lee, J. C., and Lee, J. Y (2016). Advance review on the exploitation of the prominent energy-storage element: LITHIUM. part I: from mineral and brine resources. Miner. Eng. 89, 119-137. doi: 10.1016/j.mineng.2016.01.010

Dun-Fang, L. I., Wang, C. Y., Yin, F., Chen, Y. Q., Yang, Y. Q., and Jie, X. W. (2009). Carbon reduction of lithium cobalt dioxide and its dissolution in sulfuric acid solution. Nonferrous Metals. 61, 83-86. doi: 10.1109/milcom.2009.5379889

Dunn, J. B., Gaines, L., Sullivan, J., and Wang, M. Q. (2012). Impact of recycling on cradle-to-gate energy consumption and greenhouse gas emissions of automotive lithium-ion batteries. Environ. Sci. Tech. 46, 12704-12710. doi: $10.1021 / \mathrm{es} 302420 \mathrm{z}$

Etacheri, V., Marom, R., Elazari, R., Salitra, G., and Aurbach, D. (2011). Challenges in the development of advanced Li-ion batteries: a review. Energy Environ. Sci. 4, 3243-3240. doi: 10.1039/c1ee01598b

Gao, G., He, X., Lou, X., Jiao, Z., and Chen, S. (2019). A citric acid/Na2S2O3 system for the efficient leaching of valuable metals from spent lithium-ion batteries. JOM 10, 3673-3681. doi: 10.1007/s11837-019-03629-y

Guo, Y., Li, F., Zhu, H., Li, G., Huang, J., and He, W. (2016). Leaching lithium from the anode electrode materials of spent lithium-ion batteries by hydrochloric acid (HCl). Waste Manag. 51, 227-233. doi: 10.1016/j.wasman.2015.11.036

Harper, G., Sommerville, R., Kendrick, E., Driscoll, L., Slater, P., Stolkin, R., et al. (2019). Recycling lithium-ion batteries from electric vehicles. Nature 575, 75-86. doi: 10.1038/s41586-019-1682-5

Huang, B., Li, X., Wang, Z., Guo, H., Li, S., and Wang, J. (2014). A comprehensive study on electrochemical performance of Mn-surface-modified LiNi0.8Co0.15Al0.05O2 synthesized by an in situ oxidizing-coating method. J. Power Sources 252, 200-207. doi: 10.1016/j.jpowsour.2013.11.092
Huang, B., Pan, Z., Su, X., and An, L. (2018). Recycling of lithium-ion batteries: recent advances and perspectives. J. Power Sources 399, 274-286. doi: 10.1016/j.jpowsour.2018.07.116

Jha, M. K., Kumari, A., Jha, A. K., Kumar, V., Hait, J., and Pandey, B. D. (2013). Recovery of lithium and cobalt from waste lithium ion batteries of $\mathrm{m}$ obile phone. Waste Manag. 33, 1890-1897. doi: 10.1016/j.wasman.2013.05.008

Jing, W. Jinglong, L. Hui, L. Dongbin, W. (2018). Status and prospects of treatment methods for valuable metals in spent lithium-ion battery. Hot Work Technol. 22, 12-15. doi: 10.14158/j.cnki.1001-3814

Lee, C. K., and Rhee, K. (2003). Reductive leaching of cathodic active materials from lithium ion battery wastes. Hydrometallurgy 68, 5-10. doi: $10.1016 / \mathrm{S} 0304-386 \mathrm{X}(02) 00167-6$

Lee, S. K., and Lee, S. H. J. N. (2000). "Molybdenum oxides as negativeelectrode materials for lithium-ion batteries," in ECS Meeting Abstracts. p. 496. doi: $10.1038 / 35035045$

Li, J., Shi, P., Wang, Z., Chen, Y., and Chang, C. C. (2009). A combined recovery process of metals in spent lithium-ion batteries. Chemosphere 77, 1132-1136. doi: 10.1016/j.chemosphere.2009.08.040

Li, L., Chen, R., Sun, F., Wu, F., and Liu, J. (2011). Preparation of LiCoO2 films from spent lithium-ion batteries by a combined recycling process. Hydrometallurgy 108, 220-225. doi: 10.1016/j.hydromet.2011.04.013

Li, L., Ge, J., Wu, F., Chen, R., Chen, S., and Wu, B. (2010). Recovery of cobalt and lithium from spent lithium ion batteries using organic citric acid as leachant. J. Hazard. Mater. 176, 288-293. doi: 10.1016/j.jhazmat.2009.11.026

Liang, S., and Qiu, K. (2012). Organic oxalate as leachant and precipitant for the recovery of valuable metals from spent lithium-ion batteries. Waste Manag. 32, 1575-1582. doi: 10.1016/j.wasman.2012.03.027

Meshram, P., Pandey, B. D., and Mankhand, T. R. (2015). Hydrometallurgical processing of spent lithium ion batteries (LIBs) in the presence of a reducing agent with emphasis on kinetics of leaching. Chem. Eng. J. 281, 418-427. doi: 10.1016/j.cej.2015.06.071

Meshram, P., Pandey, B. D., and Mankhand, T. R. M. (2016). Process optimization and kinetics for leaching of rare earth metals from the spent Ni-metal hydride batteries. Waste Manage. 51, 196-203. doi: 10.1016/j.wasman.2015.12.018

Mishra, D., Kim, D. J., Ralph, D. E., Ahn, J. G., and Rhee, Y. H. (2008). Bioleaching of metals from spent lithium ion secondary batteries using Acidithiobacillus ferrooxidans. Waste Manag. 28, 333-338. doi: 10.1016/j.wasman.2007.01.010

Mohagheghi, V., Mousavi, S. M., Vahdani, B., and Shahriari, M. (2017). R\&D project evaluation and project portfolio selection by a new interval type-2 fuzzy optimization approach. Neural Compt. Appl. 28, 3869-3888. doi: 10.1007/s00521-016-2262-3

Mossini, E., Macerata, E., Giola, M., Brambilla, L., Castiglioni, C., and Mariani, M. (2015). Radiation-induced modifications on physico chemical properties of diluted nitric acid solutions within advanced spent nuclear fuel reprocessing. J. Radioanaly. Nucl. Chem. 304, 395-400. doi: 10.1007/s10967-014-3556-5

Nan, J., Han, D., and Zuo, X. (2005). Recovery of metal values from spent lithiumion batteries with chemical deposition and solvent extraction. J. Power Sources. 152, 278-284. doi: 10.1016/j.jpowsour.2005.03.134

Niu, Z., Zou, Y., Xin, B., Shi, C., Liu, C., and Li, Y. (2014). Process controls for improving bioleaching performance of both $\mathrm{Li}$ and Co from spent lithium ion batteries at high pulp density and its thermodynamics and kinetics exploration. Chemosphere 109, 92-98. doi: 10.1016/j.chemosphere.2014.02.059

Pattipati, B., Balasingam, B., Avvari, G. V., Pattipati, K. R., and Barshalom, Y. (2014). Open circuit voltage characterization of lithium-ion batteries. J. Power Sources 269, 317-333. doi: 10.1016/j.jpowsour.2014. 06.152

Pinna, E. G., Ruiz, M. C., Ojeda, M. W., and Rodriguez, M. H. (2016). Cathodes of spent Li-ion batteries: Dissolution with phosphoric acid and recovery of lithium and cobalt from leach liquors. Hydrometallurgy 167, 66-71. doi: 10.1016/j.hydromet.2016.10.024

Schakman, O., Dehoux, M., Bouchuari, S., Delaere, S., Lause, P., Decroly, N., et al. (2014). An approach to beneficiation of spent lithium-ion batteries for recovery of materials [Dissertations theses Gradworks]. Golden: Colorado school of mines.

Shih, Y. J., Chien, S. K., Jhang, S. R., and Lin, Y. C. (2019). Chemical leaching, precipitation and solvent extraction for sequential separation of valuable metals in cathode material of spent lithium ion batteries. J. Taiwan Inst. Chem. Eng. 100, 151-159. doi: 10.1016/j.jtice.2019.04.017 
Song, J. Y., Wang, Y., and Wan, C. C. (1999). Review of gel-type polymer electrolytes for lithium-ion batteries. J. Power Sources 77, 183-197. doi: 10.1016/S0378-7753(98)00193-1

Song, X., Hu, T., Liang, C., Long, H. L., Zhou, L., Song, W., et al. (2017). Direct regeneration of cathode materials from spent lithium iron phosphate batteries using a solid phase sintering method. RSC Adv. 7, 4783-4790. doi: 10.1039/C6RA27210J

Villen-Guzman, M., Arhoun, B., Vereda-Alonso, C., Gomez-Lahoz, C., RodriguezMaroto, J. M., and Paz-Garcia, J. M. (2019). Electrodialytic processes in solid matrices. New insights into battery recycling. A review. J. Chem. Tech. Biotechnol. 94, 1727-1738. doi: 10.1002/jctb.5940

Yang, Y., Meng, X., Cao, H., Lin, X., Liu, C., Sun, Y., et al. (2018). Selective recovery of lithium from spent lithium iron phosphate batteries: a sustainable process. Green Chem. 20:3121-33. doi: 10.1039/c7gc03376a

Yu, M., Zhang, Z., Xue, F., Yang, B., Guo, G., and Qiu, J. (2019). A more simple and efficient process for recovery of cobalt and lithium from spent lithium-ion batteries with citric acid. Sep Purif Technol. 215, 398-402. doi: 10.1016/j.seppur.2019.01.027

Zeng, X., Li, J., and Shen, B. (2015). Novel approach to recover cobalt and lithium from spent lithium-ion battery using oxalic acid. J. Hazard. Mater. 295, 112-118. doi: 10.1016/j.jhazmat.2015.02.064
Zhang, G., Du, Z., He, Y., Wang, H., Xie, W., and Zhang, T. (2019). A sustainable process for the recovery of anode and cathode materials derived from spent lithium-ion batteries. Sustainability 11:2363. doi: 10.3390/su11082363

Zhang, P., Yokoyama, T., Itabashi, O., Wakui, Y., and Inoue, K. J. H. (1998). Hydrometallurgical process for recovery of metal values from spent nickel-metal hydride secondary batteries. Hydrometallurgy 50, 61-75. doi: 10.1016/S0304-386X(98)00046-2

Zhu, J. (2014). Synthesis, characterization and performance of cathodes for lithium ion batteries. Solid State Sci. 38, 79-84. doi: 10.1016/j.electacta.2014.02.147

Conflict of Interest: The authors declare that the research was conducted in the absence of any commercial or financial relationships that could be construed as a potential conflict of interest.

Copyright (c) 2020 Zhou, Yang, Du, Gong and Luo. This is an open-access article distributed under the terms of the Creative Commons Attribution License (CC BY). The use, distribution or reproduction in other forums is permitted, provided the original author(s) and the copyright owner(s) are credited and that the original publication in this journal is cited, in accordance with accepted academic practice. No use, distribution or reproduction is permitted which does not comply with these terms. 